Проблемна стаття / Problem article

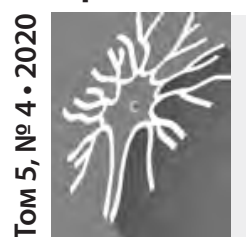

PainMedicine Journal

Медицина Болю // Медицина Боли

www. painmedicine.org.ua

Міждисциплінарний • Науково-практичний журнал

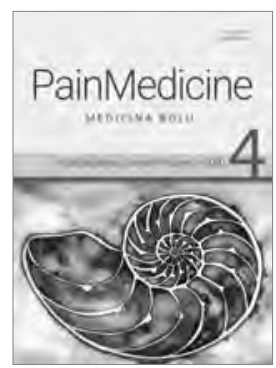

DOI: 10.31636/pmjua.v5i4.1

\title{
COVID-19 і головний біль
}

\author{
${ }^{1}$ Гончар А. В., ${ }^{2,3}$ Ковальчук П. В., ${ }^{4}$ Катілов О. В. \\ 1Універсальна клініка "Оберіг", м. Київ \\ 2Медичний центр "Evidence - сучасна педіатрія", м. Вінниця \\ 'Центр сучасної діагностики "Нейромед", м. Вінниця \\ ${ }^{4}$ Вінницький національний медичний університет ім. М. І. Пирогова, м. Вінниця
}

Резюме. Від початку пандемії COVID-19 учені всього світу інтенсивно праццюють над вивченням цุього захворювання та його взаємозв'язку з іншими патологічними станами. В даному огляді оцінюється специифічність головного болю у пацุієнтів, які перенесли інфекц̧ію COVID-19, в розрізі диференційного діагнозу. Зважаючи на подальще зростання кількості випадків захворювання, дана інформація стане в нагоді як лікарям, що працюють з такими пацієнтами, так і спеціалістам з головного болю.

Ключові слова: головний біль, COVID-19, головний біль на тлі вірусного інфекційного захворювання, диференціийний діагноз, неврологія

SARS-CoV-2 відомий не тільки своєю здатністю порушувати дихальні функції, а також викликати ураження багатьох органів та систем. В огляді Kuan-Po Peng [1] розглядаються останні дослідження, які описують зв'язок захворювання і уражень нервової системи, в тому числі головного болю. Зокрема, описано випадки ураження нервової системи у вигляді церебральних венозних тромбозів [2], транзиторних ішемічних атак [3], інсульту [4], демієлінізуючих захворювань - запальної полірадикулонейропатії Гійєна - Барре [5] та синдрому Міллера - Фішера [6], гострого розсіяного енцефаломієліту [7], гострої некротизуючої енцефалопатії [8]. Частота ускладнень з боку нервової системи невисока, порівняно з такою частотою у неспецифічних для ЦНС респіраторних вірусів, і значно нижча за таку у тропних, однак через брак даних, в тому числі відсутність можливості оцінювати віддалені неврологічні наслідки, остаточні висновки робити зарано. Що ж стосу- ється головного болю, виникає питання - чи має він специфічну асоціацію з COVID-19 чи $є$ неспецифічним симптомом?

У проспективному дослідженні, в якому брали участь 130 пацієнтів, Caronna et al. 75\% $(\mathrm{n}=97)$ повідомляе про наявність у них головного болю, що мав риси мігренозного, у 24 \% [9]. У дослідженні, проведеному з участю 580 пацієнтів, Trigo Lopez et al. описують головний біль у 130 осіб, у половини з яких він мав риси головного болю напруження [10]. Описано серію випадків з Бразилії, у 73 осіб з COVID-19 на головний біль скаржились 64,4 \% пацієнтів, характеризувавши його частіше як такий, що мав мігренеподібні риси [11]. У проспективному дослідженні Caronna et al., пацієнтів після перенесеного ковіду спостерігали протягом 6 тижнів і виявили, що у третини з них спостерігався щоденний постійний головний біль; причому в декого це був єдиний залишковий симптом [9]. У двох 
дослідженнях виявили позитивний зв'язок між головним болем та втратою нюху (аносмією) /смаку (агевзією): у 54,6 \% пацієнтів з COVID-19 та головним болем спостерігались порушення нюху та смаку порівняно 3 18,2\% без головного болю в дослідженні Caronna et al. [9] та відповідно 46,7 \% порівняно з 18,7\% у дослідженні Trigo Lopez et al. [12]. У дослідженні з Бразилії також виявлено, що в пацієнтів 3 аносмією та агевзією частіше розвивався головний біль порівняно з пацієнтами без цих ознак - 83 \% та 47 \% [11]. Politi et al. повідомив про випадок COVID-19 з аносмією, де на MPT було виявлено тимчасово змінений сигнал в нюховій цибулині та задній прямій звивині. Наскільки часто трапляються такі зміни сигналу, наразі невідомо [13].

У дітей головний біль у більшості випадків є первинним (мігрень, головний біль напруженого типу); до найрозповсюдженіших причин вторинного головного болю відносять незагрозливі для життя вторинні типи - післятравматичний головний біль, біль на тлі системних інфекційних захворювань (у першу чергу вірусних, куди відноситься й COVID-19) і захворювань ЛОР-органів (у молодшому віці - отити, в старшому - риносинусити) [14]. Згідно 3 дослідженням групи розробників застосунку COVID Symptom Study у Великобританії [15], симптоми у дітей відрізняються від класичних у дорослих. Головний біль був другим найрозповсюдженішим після втоми симптомом (53\%), а гастроінтестинальні розлади рекомендовано використовувати як показання до тестування [16]. В той час як останні огляди з бази PubMed стосовно коронавірусної інфекції у дітей не вказують цей симптом взагалі, однак розповсюдженими є гастроінтестинальні симптоми і висип $[17,18]$.

Тож чи можна вважати, що COVID-19 має специфічний зв'язок з головним болем? Відповідь - найімовірніше, ні. Головний біль дуже поширений серед пацієнтів 3 гострими респіраторними інфекціями - трапляється у 68-100 \% при грипі, у 83 \% при аденовірусній інфекції та майже у кожного з риновірусною інфекцією. Головний біль під час інфекції є варіантом фізіологічної відповіді організму на гострий запальний процес [19]. Dr. Rozen у своїй статті в журналі Cеphalalgia наводить дані, що під час пандемії російського та азіатського грипу в 1890 році у 75-83 \% пацієнтів був головний біль під час гострого періоду хвороби, а в декого навіть залишився стійким симптомом після одужання протягом тижнів чи навіть місяців, нагадуючи щоденний персистуючий головний біль [20]. Подібний тип головного болю описує Carorra et al. у третини пацієнтів, яких спостерігав його протягом 6 тижнів після одужання від COVID-19 [9]. Згідно з Міжнародною класифікацією головного болю 3-го перегляду (МКГБ-3), головний біль у пацієнтів з COVID-19 підходить під визначення:
9.2.2.1 Гострий головний біль, асоційований із системною вірусною інфекцією [21].

Критерії діагнозу:

А. Головний біль будь-якої тривалості, який відповідає критерію С.

В. Обидва з наступного:

1. Діагностована системна вірусна інфекція.

2. Відсутність доказів менінгіту чи енцефаліту.

С. Докази причинно-наслідкового зв'язку, принаймні 2 з наступних:

1. Розвиток головного болю пов'язаний у часі з початком симптомів вірусної інфекції.

2. Головний біль значно посилився разом 3 посиленням симптомів вірусної інфекції.

3. Головний біль значно полегшився або минув разом $з$ полегшенням або зникненням симптомів вірусної інфекції.

4. Головний біль має одну з/або обидві характеристики:

- дифузний біль;

- середньої або сильної інтенсивності.

D. Не описується краще іншим діагнозом МКГБ-3.

Патогенез такого головного болю до кінця не з'ясований. Існує теорія, що мікроорганізми можуть активувати запальні молекули та медіатори болю, такі як оксид азоту, простагландини та цитокіни [22]. Як і при COVID-19-інфекції, виділяється велика кількість прозапальних цитокінів - IL-1 $\beta$, IL-6 i TNF- $\alpha$, що беруть участь у патогенезі больових станів [23]. Існує також інша гіпотеза - тригером головного болю може слугувати лихоманка, яка викликається активацією прозапальними цитокінами гіпоталамуса [24]. У перехресному дослідженні Rehab Magdy et al., у 172 пацієнтів з головним болем внаслідок COVID-19-інфекції виявили такі фактори вищої частоти та інтенсивності головного болю: жіноча стать, лихоманка, дегідратація, наявність в анамнезі первинних головних болів (мігрені та головного болю напруження), супутні захворювання [24]. Частіше головний біль описували як тиснучий, дифузний, помірної та високої інтенсивності. Цікаво, що ні рівень лімфоцитів, ні рівень С-реактивного білка, феритину чи $\mathrm{D}$-димеру не мали суттєвого звязку з частотою та інтенсивністю головного болю у пацієнтів з COVID-19 [25].

Варто також пам'ятати, що в діагностиці причин вторинного головного болю загальноприйнятим є використання методу “червоних прапорців” [19, 26]:

- перший і “найгірший” в житті головний біль, особливо з раптовим початком;

- новий прогресуючий головний біль, що тримається днями, новий сильний головний біль (до 4 тижнів), кластерний головний біль, посилення інтенсивності, частоти, тривалості, характеру нападів; 
- неврологічний дефіцит (наприклад, диплопія, сенсорні розлади, слабкість, атаксія), змінений рівень свідомості, однак при COVID-19 втрату нюху не варто розглядати як симптом ураження передньої черепної ямки без інших симптомів (психічних порушень, набряку чи атрофії диска зорового нерва, інших вогнищевих симптомів чи ознак підвищення внутрішньочерепного тиску);

- посилення болю або погіршення загального стану при натужуванні, кашлі, чханні, нахилі голови, рухах очима, прийомі Вальсальви;

- головному болю передувала травма голови, шиї або інша значна травма, або ж її ознаки - синяки, рубці, пошкодження шкірних покривів, факти про жорстоке поводження 3 дитиною в анамнезі;

- головний біль, що супроводжується ригідністю шийних м'язів і/або жаром;

- неадекватна відповідь на оптимальну терапію;

- новоз'явлений біль у віці $<7$ років (за різними джерелами - від 4 до 7) і після 65 років;

- головний біль, пов'язаний 3 нудотою/блюванням, особливо ранковими;

- фебрилітет (без контексту), втрата ваги;

- артеріальна гіпертонія;

- можливий вплив токсичних речовин;

- незвичний анамнез або характер головного болю, який не відповідає критеріям діагнозу “мігрень”, “головний біль напруженого типу” або іншого головного болю згідно 3 критеріями міжнародної класифікації головного болю 3-го перегляду;

- онкологічне захворювання або СНІД в анамнезі, скомпрометований імунітет (прийом імуносупресорів - цитостатиків, кортикостероїдів);

- наявність лікворошунтуючої системи.

При навності вищевказаних ознак варто детальніше оцінювати неврологічний статус пацієнта; можливе проведення нейровізуалізації та вирішення питання додатково про виконання люмбальної пункції за відсутності протипоказань для уточнення дігнозу.

\section{Висновок}

Головний біль є поширеним симптомом у пацієнтів з COVID-19-інфекцією і зазвичай має такі ж характеристики, як при інших гострих вірусних захворюваннях. Останні дані свідчать, що у деяких осіб з певними факторами ризику частота й інтенсивність головного болю вища. Необхідно провести подальші дослідження, в тому числі у пацієнтів з різними формами захворювання, для детальнішого розуміння специфічності асоціації даного симптому з COVID-19-інфекцією та глибшого розуміння його патогенезу.

У диференційному діагнозі головного болю, особливо при наявності супутніх симптомів та факторів ризику (підвищення температури, загальна слабкість, втома, втрата нюху, контакт з хворим; у дітей до цього переліку варто включити шкірні та гастроентеральні прояви), варто розглядати захворювання на COVID-19. Сама по собі комбінація головного болю і підтвердженого інфікування не є імперативом до проведення додаткових досліджень нервової системи (МРТ головного мозку з і без контрастування, СКТ, люмбальна пункція). Тактика призначення додаткових методів досліджень грунтується на клінічній картині, можливе використання методу “червоних прапорців” - симптомів, які 3 високою ймовірністю вказують на наявність клінічно значимої патології. До особливостей “червоних прапорців” при цьому захворюванні можна віднести виключення втрати нюху, позаяк цей симптом є високоспецифічним для коронавірусної інфекції, в той час як поза контекстом інфікування від може свідчити про ураження передньої черепної ямки (переломи, пухлини). COVID-19, вірогідно, здатен викликати ураження нервової системи, однак частота цих ускладнень не встановлена i, за попередніми даними, відносно невисока серед інших інфекційних причин.

\section{References}

1. Peng K-P. Association between COVID-19 and headache: What evidence and history tell us. Cephalalgia [Internet]. SAGE Publications; 2020 Nov;40(13):1403-5. Available from: https://doi.org/ $10.1177 / 0333102420965969$

2. Tu TM, Goh C, Tan YK, Leow AS, Pang YZ, Chien J, et al. Cerebral Venous Thrombosis in Patients with COVID-19 Infection: a Case Series and Systematic Review. Journal of Stroke and Cerebrovascular Diseases [Internet]. Elsevier BV; 2020 Dec;29(12):105379. Available from: https://doi.org/10.1016/j.jstrokecerebrovasdis.2020.105379

3. Mantero V, Basilico P, Costantino G, Pozzetti U, Rigamonti A, Salmaggi A. Recurrent Transient Ischemic Attack in a Young Patient with COVID-19. Journal of Clinical Neurology [Internet]. Korean Neurological Association; 2020;16(3):513. Available from: https://doi.org/ 10.3988/jcn.2020.16.3.513

4. Divani AA, Andalib S, Di Napoli M, Lattanzi S, Hussain MS, Biller J, et al. Coronavirus Disease 2019 and Stroke: Clinical Manifestations and Pathophysiological Insights. Journal of Stroke and Cerebrovascular Diseases [Internet]. Elsevier BV; 2020 Aug;29(8):104941. Available from: https://doi.org/10.1016/j.jstrokecerebrovasdis.2020.104941

5. Toscano G, Palmerini F, Ravaglia S, Ruiz L, Invernizzi P, Cuzzoni MG, et al. Guillain-Barré Syndrome Associated with SARS-CoV-2. New England Journal of Medicine [Internet]. Massachusetts Medical Society; 2020 Jun 25;382(26):2574-6. Available from: https://doi.org/ $10.1056 /$ nejmc 2009191

6. Gutiérrez-Ortiz C, Méndez-Guerrero A, Rodrigo-Rey S, San Pedro-Murillo E, Bermejo-Guerrero L, Gordo-Mañas R, et al. Miller Fisher syndrome and polyneuritis cranialis in COVID-19. Neurology [Internet]. Ovid Technologies (Wolters Kluwer Health); 2020 Apr 17;95(5):e601-e605. Available from: https://doi.org/10.1212/wnl.0000000000 009619

7. Souhel Najjar et al., Central nervous system complications associated with SARS-CoV-2 infection: integrative concepts of pathophysiology and case reports J Neuroinflammation. 2020; 17: 231.

8. Najjar S, Najjar A, Chong DJ, Pramanik BK, Kirsch C, Kuzniecky RI, et al. Central nervous system complications associated with SARSCoV-2 infection: integrative concepts of pathophysiology and case reports. Journal of Neuroinflammation [Internet]. Springer Science and Business Media LLC; 2020 Aug 6;17(1). Available from: https://doi. org/10.1186/s12974-020-01896-0

9. Poyiadji N, Shahin G, Noujaim D, Stone M, Patel S, Griffith B. COVID-19-associated Acute Hemorrhagic Necrotizing Encephalopathy: Imaging Features. Radiology [Internet]. Radiological Society of North America (RSNA); 2020 Aug;296(2):E119-E120. Available from: 
https://doi.org/10.1148/radiol.2020201187

10. Caronna E, Ballvé A, Llauradó A, Gallardo VJ, Ariton DM, Lallana S, et al. Headache: A striking prodromal and persistent symptom, predictive of COVID-19 clinical evolution. Cephalalgia [Internet]. SAGE Publications; 2020 Nov;40(13):1410-21. Available from: https://doi.org/ $10.1177 / 0333102420965157$

11. Trigo López J, García-Azorín D, Planchuelo-Gómez Á, García-Iglesias C, Dueñas-Gutiérrez C, Guerrero ÁL. Phenotypic characterization of acute headache attributed to SARS-CoV-2: An ICHD-3 validation study on 106 hospitalized patients. Cephalalgia [Internet]. SAGE Publications; 2020 Nov;40(13):1432-42. Available from: https://doi.org/10.1177/ 0333102420965146

12. Sampaio Rocha-Filho PA, Magalhães JE. Headache associated with COVID-19: Frequency, characteristics and association with anosmia and ageusia. Cephalalgia [Internet]. SAGE Publications; 2020 Nov;40 (13):1443-51. Available from: https://doi.org/10.1177/0333102420 966770

13. Trigo J, García-Azorín D, Planchuelo-Gómez Á, Martínez-Pías E, Talavera B, Hernández-Pérez I, et al. Factors associated with the presence of headache in hospitalized COVID-19 patients and impact on prognosis: a retrospective cohort study. The Journal of Headache and Pain [Internet]. Springer Science and Business Media LLC; 2020 Jul 29;21(1). Available from: https://doi.org/10.1186/s10194-020-01165-8

14. Politi LS, Salsano E, Grimaldi M. Magnetic Resonance Imaging Alteration of the Brain in a Patient With Coronavirus Disease 2019 (COVID-19) and Anosmia. JAMA Neurology [Internet]. American Medical Association (AMA); 2020 Aug 1;77(8):1028. Available from: https://doi.org/10.1001/jamaneurol.2020.2125

15. Bonfert M, Ebinger F, Blankenburg M, Ertl-Wagner B, Heinen F, Roser T. Primary versus Secondary Headache in Children: A Frequent Diagnostic Challenge in Clinical Routine. Neuropediatrics [Internet]. Georg Thieme Verlag KG; 2013 Jan 3;44(01):034-9. Available from: https:// doi.org/10.1055/s-0032-1332743

16. Back to school: the real symptoms to look out for in children, September 7, 2020, accessed online 29.11.2020 https://covid.joinzoe.com/ post/back-to-school

17. Mayor S. Covid-19: UK studies find gastrointestinal symptoms are common in children. BMJ [Internet]. BMJ; 2020 Sep 7;m3484. Available from: https://doi.org/10.1136/bmj.m3484

18. Cui X, Zhang T, Zheng J, Zhang J, Si P, Xu Y, et al. Children with coronavirus disease 2019: A review of demographic, clinical, laboratory, and

\section{COVID-19 and headache}

${ }^{1}$ Honchar A. V., ${ }^{2,3}$ Kovalchuk P. V., ${ }^{4}$ Katilov O. V.

${ }^{1}$ Universal Clinic "Oberig”, Kyiv

${ }^{2}$ Medical Center "Evidence - Modern Pediatrics", Vinnytsia

${ }^{3}$ Diagnostic Imaging Center "Neuromed", Vinnytsia

${ }^{4}$ National Pirogov Memorial Medical University, Vinnytsia

Abstract. Since the start of the COVID-19 pandemic scientists from all over the world have been working thoroughly to study this disease and its connections with other pathological conditions. In this review the specificity of headache in patients who had had COVID-19 infection in terms of differential diagnosis is estimated. Due to increasing amount of cases, this information will be extremely helpful for doctors who are managing such patient as well as for headache specialists.

Key words: headache, COVID-19, headache attributed to viral illness, differential diagnosis, neurology imaging features in pediatric patients. Journal of Medical Virology [Internet]. Wiley; 2020 Jun 2;92(9):1501-10. Available from: https://doi. org/10.1002/jmv.26023

19. Ciuca IM. COVID-19 in Children: An Ample Review. Risk Management and Healthcare Policy [Internet]. Informa UK Limited; 2020 Jun;Volume 13:661-9. Available from: https://doi.org/10.2147/rmhp.s257180

20. Peng K-P. Association between COVID-19 and headache: What evidence and history tell us. Cephalalgia [Internet]. SAGE Publications; 2020 Nov;40(13):1403-5. Available from: https://doi.org/10.1177/ 0333102420965969

21. Rozen TD. Daily persistent headache after a viral illness during a worldwide pandemic may not be a new occurrence: Lessons from the 1890 Russian/Asiatic flu. Cephalalgia [Internet]. SAGE Publications; 2020 Nov;40(13):1406-9. Available from: https://doi.org/10.1177/ 0333102420965132

22. Headache Classification Committee of the International Headache Society (IHS) The International Classification of Headache Disorders, 3rd edition. Cephalalgia [Internet]. SAGE Publications; 2018 Jan;38(1):1211. Available from: https://doi.org/10.1177/0333102417738202

23. Marchioni E, Tavazzi E, Bono G, Minoli L, Bastianello S, Sinforiani E, et al. Headache Attributed to Infection: Observations on the IHS Classification (ICHD-II). Cephalalgia [Internet]. SAGE Publications; 2006 Dec;26(12):1427-33. Available from: https://doi.org/10.1111/j.14682982.2006.01213.x

24. Ragab D, Salah Eldin H, Taeimah M, Khattab R, Salem R. The COVID-19 Cytokine Storm; What We Know So Far. Frontiers in Immunology [Internet]. Frontiers Media SA; 2020 Jun 16;11. Available from: https:// doi.org/10.3389/fimmu.2020.01446

25. Marinis MD, Welch K. Headache Associated with Non-Cephalic Infections: Classification and Mechanisms. Cephalalgia [Internet]. SAGE Publications; 1992 Aug;12(4):197-201. Available from: https://doi. org/10.1046/j.1468-2982.1992.1204197.x

26. Magdy R, Hussein M, Ragaie C, Abdel-Hamid HM, Khallaf A, Rizk HI, et al. Characteristics of headache attributed to COVID-19 infection and predictors of its frequency and intensity: A cross sectional study. Cephalalgia [Internet]. SAGE Publications; 2020 Nov; 40(13):1422-31. Available from: https://doi.org/10.1177/0333102420965140

27. Kovalchuk PV, Katilov OV, Panenko SO. Modern approaches to diagnostics and treatment of migraine in children. Pain medicine [Internet]. Interdisciplinar Academy of Pain Medicine; 2019 Feb 21;3(4):41-53. Available from: https://doi.org/10.31636/pmjua.v3i4.2

\section{COVID-19 и головная боль}

${ }^{1}$ Гончар А. В., ${ }^{2,3}$ Ковальчук П. В., ${ }^{4}$ Катилов А. В.

'Универсальная клиника “Обериг”, г. Киев

${ }^{2}$ Медицинский центр "Evidence - современная педиатрия", г. Виннициа

${ }^{3}$ Центр современной диагностики “Нейромед”, г. Винницза

${ }^{4}$ Винницикий национальный медициннский университет им. Н.И. Пирогова, г. Винница

Резюме. С момента начала пандемии COVID-19 ученые всего мира интенсивно работают над изучением этого заболевания и его связей с другими патологическими состояниями. В этом обзоре оценивается специфичность головной боли у пацииентов, переболевших COVID-19, в разрезе дифференциальной диагностики. Учитывая дальнейшее распространение заболевания и стремительный рост новых случаев, данная информация будет полезна не только докторам, работающим с такими пацииентами, но и специиалистам по головной боли.

Ключевые слова: головная боль, COVID-19, головная боль на фоне вирусного инфекциионого заболевания, дифференцииальный диагноз, неврология 